\title{
HEITOR VILLA-LOBOS E O AMBIENTE ARTÍSTICO PARISIENSE: CONVERTENDO-SE EM UM MÚSICO BRASILEIRO*
}

\author{
Paulo Renato Guérios
}

Em julho de 1923, o compositor brasileiro Heitor Villa-Lobos chegava a Paris como um completo desconhecido. Haviam passado cerca de cinco anos desde seu primeiro grande concerto no Brasil; Villa-Lobos viajava então à Europa com a intenção de divulgar sua obra.

Sua entrada nos círculos artísticos parisienses deu-se por intermédio do grupo de pintores e escritores modernistas brasileiros que ele conhecera em 1922, logo antes da Semana de Arte M oderna, em São Paulo. Em seguida à sua chegada, o compositor foi convidado para um almoço no studio da pintora Tarsila do Amaral, no qual estariam presentes, entre outros, o poeta Sérgio Milliet, o pianista J oão de Souza Lima, o escritor Oswald de Andrade e, entre os parisienses, o poeta Blaise Cendrars, o músico Erik Satie e o poeta e pintor J ean Cocteau.

Nesse dia, após o almoço, os artistas entretinham-se em animada conversação quando o assunto se desviou para a arte da improvisação musical. Villa-Lobos, que já tinha uma extensa obra composta para piano solo, sentou-se então ao Erard de concerto de Tarsila para improvisar. Imediatamente, J ean Cocteau, conhecido por suas boutades e por suas atitudes espirituosas, sentou-se sob o piano, no chão, "para que pudesse ouvir meIhor". A o final da improvisação de Villa-Lobos, no entanto, Cocteau voltou à sua poltrona e atacou ferrenhamente o que ouvira: em sua opinião, a música que o compositor apresentara não passava de uma emulação dos estilos de Debussy e Ravel. Villa-Lobos imediatamente começou outra improvisação; Cocteau, no entanto, continuava intransigente, questionando agora se uma improvisação podia ser feita dessa forma, sob encomenda. Os dois artistas começaram a discutir acaloradamente, e por pouco não brigaram¹.

Esse encontro pode ser tomado como um momento fundamental da inflexão que a trajetória pessoal e artística de Villa-Lobos sofreu devido à sua viagem a Paris: foi somente após essa viagem que ele passou a dedi- 
car seus esforços à produção de uma música de caráter nacional . O presente artigo é um esforço para compreender por que essa inflexão ocorreu nesse momento e por que o projeto artístico de Villa-Lobos assumiu, a partir de então, esse conteúdo específico.

O que o evento descrito marca é um momento de quebra de expectativa: o compositor, que esperava fazer grande sucesso na capital francesa, tinha sua arte rejeitada por uma das figuras mais importantes no cenário artístico da cidade. Um acontecimento como esse é perpassado por inúmeros vetores sociais. De um lado, temos um artista estrangeiro, vindo da "periferia", recém-chegado ao grande centro cultural da época; de outro, um artista parisiense, completamente estabelecido em seu meio. Mais que uma questão puramente estética, estava então sendo colocada em jogo toda uma série de conteúdos culturais, legitimidades, representações e hierarquias.

Portanto, para compreendermos não apenas esse encontro mas a permanência de Villa-Lobos em Paris, precisamos explorar cuidadosamente a configuração sociohistórica em que ambos ocorrem. Não traçaremos, contudo, um "contexto" global no qual os personagens estariam "imersos". Tal abordagem empobreceria as possibilidades analíticas, visto que, como afirma Bensa (1998:46), “o contexto é imanente às práticas, e faz parte delas". Enfocaremos, sim, as práticas e as relações estabelecidas entre os diferentes atores sociais envolvidos, determinando através da pesquisa empírica suas propriedades sociais, suas aspirações e o momento que viviam em suas trajetórias de vida.

Esta análise servirá como ponto de partida para enfocarmos um assunto mais amplo. De fato, o estudo das trajetórias de seus personagens permite-nos falar a respeito do regime de funcionamento dos fluxos culturais entre centro e periferia, tomando como exemplo os ambientes musicais da França e do Brasil na década de 20. Com o auxílio desse material empírico, poderemos indicar quais foram as práticas e mecanismos sociais através dos quais as posições sociais desses personagens foram basculadas e suas diferenças legitimadas.

Iniciaremos o artigo traçando um esboço da trajetória de Heitor VillaLobos até seu encontro com Cocteau em Paris. A seguir, enfocaremos o processo de transformação de suas concepções acerca da música brasileira e de sua própria obra enquanto ele se encontrava na capital francesa. Por fim, discutiremos os mecanismos e práticas sociais mediante os quais essa transformação se operou. 


\section{Heitor Villa-Lobos, um compositor carioca}

Em março de 1887, quando Heitor Villa-Lobos nasceu, muitas coisas estavam prestes a mudar em sua cidade natal, o Rio de J aneiro. Um imperador frágil e alquebrado era o único guardião de um sistema de governo que já há alguns anos se revelava disfuncional. Pouco mais de dois anos depois, o imperador e sua família foram banidos, e uma República foi proclamada no Brasil.

A transição para a nova forma de governo teve grande impacto sobre as artes: o imaginário ligado à liberdade e à modernidade, tão difundido nos primeiros anos após a proclamação, criou um ambiente favorável para mudanças nas opções estéticas. No campo da música erudita, alguns artistas aproveitaram essa oportunidade para operar uma grande reestruturação na maior instituição de ensino musical do país: menos de dois meses após o final do Império, um decreto transformou o Imperial Conservatório de Música em Instituto Nacional de Música.

Essa mudança de nome sinalizava o desejo de mudanças mais profundas. De fato, até então, a música erudita feita no Brasil circulava exclusivamente ao redor da Corte. Foi em 1841 que Francisco M anuel da Silva "depôs perante o trono" uma solicitação para a criação do Imperial Conservatório, um "meio civilizador" que poderia colocar o Brasil no concerto das "nações mais cultas" (Mello 1947 [1908]:219). Antes disso, a música erudita feita no Brasil estava praticamente restrita à música para funções eclesiásticas, composta por mestres-capelas como M arcos Portugal e o padre J osé M aurício. O Imperial Conservatório, no entanto, nunca chegaria a constituir-se como uma instituição sólida, tendo mesmo perdido esse espaço institucional ao ser subordinado à Escola de Belas-Artes em 1855. O Império também apoiou a criação da Imperial Academia de M úsica e Ópera Nacional por Dom J osé A mat, um imigrante espanhol que começou a implementar seu projeto em 1857, e que assim tentou constituir um campo para a criação de óperas "nacionais" brasileiras. Na prática, o elemento "nacional" das obras apresentadas na Imperial Academia restringiu-se quase que totalmente ao uso da língua portuguesa, em versões traduzidas de óperas como Norma e La Traviatta - e os próprios cantores dos papéis principais das apresentações da Imperial Academia eram quase sempre estrangeiros, o que fazia com que mesmo o "português" cantado fosse incompreensível para a platéia (Azevedo 1938:592). De fato, a preeminência da estética italiana no Brasil dos anos do Império foi tão acentuada que o debate dos críticos a respeito da primeira ópera de Antônio Carlos Gomes, A N oite do Castello, foi sobre a 
conveniência ou não de o compositor livrar-se da influência de Verdi para aplicar-se à estética de Rossini e Donizetti. Único grande nome da música erudita nacional de então, Carlos Gomes estreou seu maior sucesso, a ópera II Guarany, cantada em italiano, no Teatro Scala de M ilão (Azevedo 1936:208).

Quando o compositor Leopoldo Miguéz assumiu a direção do então Instituto Nacional de Música, em 1890, fez questão de impor uma estética "moderna" em face do "conservadorismo" ali reinante. Para M iguéz, "modernas" eram a estética alemã de Wagner e a francesa de Saint-Saëns, e "conservadorismo" significava a insistência no privilégio do canto lírico italiano; em outro plano, Wagner, Saint-Saëns, M iguéz e a República eram a modernidade que vinha substituir Verdi, o Conservatório e o imperador, constituindo um eco musical às reformas urbanas e ideológicas por que passava a capital da República. Assim, valores sociais e políticos foram atribuídos a uma forma de objetivação cultural que, à primeira vista, parece estranha a essas disputas: a estética musical. A “atualização" proposta por Miguéz para o ambiente musical erudito brasileiro foi tanto estética quanto moral.

Já no dia seguinte ao de sua nomeação como diretor do Instituto, Miguéz aboliu a cadeira de canto "por falta de professores", apesar de haver ali muitos professores de canto lírico italiano. Professores de piano concursados que se filiavam à mesma estética foram substituídos ou recolocados em cargos menores, como o de acompanhador. Os atos de Miguéz fizeram com que os defensores do bel-canto passassem a constituir a oposição ao establishment musical no Rio de J aneiro; como conseqüência dos acontecimentos, o debate estético sobre a música erudita no Rio de J aneiro foi polarizado entre a música italiana e a de Richard Wagner.

A música de Wagner representava a "modernidade" nesse debate porque foi justamente no auge da aceitação desse compositor na Europa que Miguéz e Alberto Nepomuceno, que seria o próximo diretor do Instituto, fizeram sua formação nos grandes centros musicais europeus. $\mathrm{Ne}$ pomuceno, por exemplo, estudou em Berlim e em Paris entre 1888 e 1895. Durante esses sete anos, vivenciou a glorificação do compositor alemão e assistiu ao nascer da "revolução" estética de Claude Debussy. Ao retornar ao Brasil, eram as partituras desses mestres que estavam em sua bagagem (Pereira 1995:109-111)2.

Foi no contato com esses debates que o jovem Heitor Villa-Lobos se formou. Integrante da geração que se seguiu a M iguéz e N epomuceno, Villa-Lobos compreenderia as diferentes estéticas musicais de acordo com o panorama traçado por seus antecessores: a "antiguidade" e a "nobre- 
za" da ópera italiana; a "modernidade" de Wagner e Saint-Saëns; a estética "revolucionária" de Claude Debussy.

O contato de Villa-Lobos com a música erudita iniciou-se em sua própria casa. Seu pai Raul, filho de imigrantes espanhóis, não nasceu em uma família de elite. No entanto, foi apadrinhado por Alberto Brandão, então líder da maioria na Assembléia Provincial Fluminense e criador de um conceituado colégio secundário na cidade de Vassouras. Como resultado, Raul conseguiu completar seus estudos secundários, o que constituía um privilégio no Segundo Império e mesmo durante a República Velha. A educação recebida por ele em $V$ assouras possibilitou o que, de outra forma, seria inimaginável para uma criança sem recursos: o acesso à formação erudita. Raul aproveitou-a, no entanto, para investir em mais estudos. Paralelamente a seu trabalho como funcionário público da Biblioteca Nacional, ele escreveu alguns livros didáticos e outros de história, além de traduzir obras para o português. Intelectual polígrafo, ele incluiu entre seus interesses a paixão pela música erudita: sócio do Clube Sinfônico, Raul freqüentava a ópera e tocava música de câmara em sua casa com seus amigos, além de sempre tocar seu violoncelo e seu clarinete. Em diversas ocasiões, levou seu filho Heitor a concertos e mesmo a salões musicais na casa de Alberto Brandão.

O investimento de Raul na formação musical do filho, no entanto, foi mais além. Villa-Lobos contou que seu pai adaptou para ele um pequeno violoncelo colocando um apoio em uma viola, e que o obrigava a "discernir o gênero, estilo, caráter e origem das obras musicais que [o] fazia ouvir". Por não ter constituído um amplo círculo de relações nem ter investido em uma carreira que Ihe desse maiores retornos financeiros, a iniciação precoce em música erudita foi praticamente a única herança que Raul deixou a Heitor; em 1899, aos 37 anos, ele morria vitimado pela varíola. Seu filho foi então sustentado pela mãe, que trabalhou lavando guardanapos para a Confeitaria Colombo3.

Heitor Villa-Lobos não chegou a concluir seus estudos secundários. Em 1904, contudo, inscreveu-se no Instituto Nacional de Música para ter aulas de violoncelo em um curso noturno, ao mesmo tempo que participava da orquestra de uma sociedade sinfônica, o Club Francisco Manuel. Os cursos noturnos faziam parte do projeto dos professores do Instituto para manter e ampliar o espaço da música erudita no Rio de J aneiro logo após a proclamação da República. O plano de criação desses cursos foi justificado, em março de 1900, por J osé Rodrigues Barbosa, crítico musical e professor honorário do Instituto, em um ofício no qual ele afirmou: 
“A criação de cursos noturnos é uma necessidade para o ensino profissional, e poderá proporcionar ao Instituto a formação de orquestras, dando-se ensino especial para esse fim à noite, quando pode afluir a freqüência de alunos. Como é sabido, a grande freqüência do Instituto nos cursos diurnos é quase exclusivamente de alunas, e destas mui raramente alguma se resolve a tomar parte em conjuntos instrumentais. Com os 'Cursos N oturnos' teremos a freqüência de alunos, que abraçarão a nova carreira profissional que se Ihes depara. Daí a probabilidade de formação de orquestras-modelo, as execuções das obras dos grandes mestres, e a educação musical do grande público pela audição" (apud Pereira 1995:195).

Ainda em 1904, no entanto, os cursos noturnos foram suspensos pelo novo diretor, o também compositor Henrique Oswald, sob a alegação de que eles “importa[vam] em grave prejuízo para o ensino diurno, onde podem ser aproveitados tantos professores, aliás distribuídos por classes quase sem freqüência, como são as daquele curso" (apud Pereira 1995: 195). O único registro do nome de Villa-Lobos no Instituto Nacional de Música é o que fala de seu ingresso como aluno do curso noturno (Pereira 1995:197); após 1904, ele não consta entre os alunos regularmente matriculados na instituição.

São poucos os materiais empíricos existentes sobre a trajetória de Villa-Lobos entre 1905 e 1912. Durante esse período, segundo afirmou a seus biógrafos, ele teria feito viagens pelo Brasil. Contudo, pouco se pode afirmar de positivo a respeito dessas viagens. A penas dois registros escritos, pertencentes aos arquivos do M useu Villa-Lobos, comprovam viagens que ele empreendeu: o primeiro, de um concerto em Paranaguá, cidade portuária paranaense onde, entre 1907 e 1908, Villa-Lobos viveu e trabaIhou como atendente em uma firma do comércio local, tocando em suas horas livres (Lino s/d.:87); e o segundo, de um concerto em Manaus, para onde Villa-Lobos viajou com uma companhia artística como violoncelista acompanhador de espetáculos de teatro. Os relatos de Villa-Lobos, no entanto, são muito mais extensos. Anos mais tarde, ele chegaria a afirmar que cruzara todo o interior do Brasil, incluindo os rios A mazonas e Xingu, a bordo de uma canoa. Não por acaso, esses relatos inverossímeis surgiram justamente após Villa-Lobos tornar-se um músico "nacional". Hoje parece mais plausível que o compositor os criou para que pudesse, legitimamente, evocar para si mesmo o papel do grande músico "nacional", aquele que conhecia todas as manifestações musicais de seu povo.

O caminho trilhado pelo compositor até aquele momento, no entanto, foi muito acidentado. Ao voltar de Manaus para o Rio de J aneiro, Villa- 
Lobos passou a tirar seu sustento atuando como músico de orquestra em sociedades sinfônicas, cinemas e cafés. Ao mesmo tempo, conviveu com os músicos de rua da cidade, os "chorões", em sua mai oria funcionários públicos de baixo escalão que tocavam à noite em festas como batizados, casamentos e aniversários nas casas da periferia. Em uma época em que discos e rádios eram privilégio das classes superiores, a população pobre apenas ouvia música através de grupos como os dos chorões.

Não é possível saber a intensidade e a qualidade do contato de VillaLobos com os músicos populares de sua cidade. Por um lado, ele convivia nos mesmos espaços, ocupava a mesma posição socioeconômica e aprendera a tocar o instrumento dos chorões, o violão, para o qual comporia extensa obra mais tarde; por outro, sua formação erudita e seu trabalho em orquestras separavam-no dos músicos amadores populares.

Esse outro pertencimento de Villa-Lobos o afastou da música popular em seus primeiros anos como compositor. De fato, a música popular era muito depreciada no Rio de J aneiro até 1920; após esta data, alguns estudiosos e folcloristas iniciaram sua valorização em um movimento que a tornaria um dos símbolos da nacionalidade. Mas durante a década de 10, quando um músico "sério" queria ofender seu concorrente, as categorias de acusação acionadas eram expressões como “compositor de maxixes" ou "assobiador".

As primeiras composições de Villa-Lobos, apresentadas a partir de 1915 no Rio de J aneiro, constituem uma chave fundamental para a compreensão de seus pertencimentos e atitudes: são músicas como as duas primeiras Sinfonias, o poema sinfônico O Naufrágio de Kleonicos, a ópera Izaht, as Danças Características Africanas e a Prole do Bebê. É nesse momento que a própria substância musical, aliada aos pronunciamentos do compositor, torna-se documento etnográfico indispensável à análise. Ao compreendermos os elementos estéticos acionados nas obras, podemos tirar conclusões a respeito das opções que ele fez ao longo de sua trajetória - pois é através dessas obras que ele, em uma linguagem própria, emite sob forma musical um discurso que não deixa por isso de ser social. Examinemos, então, as características de cada uma dessas obras.

As primeiras sinfonias de Villa-Lobos, conforme depoimento do próprio compositor a um biógrafo (M ariz 1949:39), foram feitas de acordo com as regras postuladas por Vincent D'Indy em seu Cours de Composition M usicale; a estética proposta por D'Indy, adotada pelos professores do Instituto Nacional de M úsica, era ligada diretamente à de Wagner. Também ligado a estéticas defendidas pelos professores do Instituto estava seu Naufrágio de Kleonicos, poema sinfônico cuja linguagem musi- 
cal é uma clara emulação dos princípios do pós-romantismo francês de Saint-Saëns ${ }^{4}$. Dessa forma, a aplicação das idéias estéticas de Wagner, D'Indy e Saint-Saëns serviriam como prova da capacidade de VillaLobos enquanto compositor em face do establishment musical carioca. Contudo, segundo o próprio Villa-Lobos em uma entrevista em 1929, vários críticos Ihe diziam que ele não poderia ser considerado um "compositor" se não tivesse uma ópera em seu repertório5. A resposta, dada "para provar vitoriosamente sua capacidade aos que o denegriam" , foi Izaht, ópera em quatro atos na qual o compositor refletiria o "Iirismo sensual de Puccini" e as "concepções wagnerianas de leitmotiv". Além de responder ao establishment do Instituto e à sua oposição, os defensores das óperas italianas, Villa-Lobos também não deixava de compor obras que utilizassem elementos da estética de Debussy: a escala de tons inteiros, empregada em suas Danças Características Africanas (cf. Wisnik 1983: 150), e a concepção de pequenas peças infantis do Children's Corner do compositor francês, presente em sua Prole do Bebê, faziam de VillaLobos um dos poucos compositores de sua época a ousarem compor uma música "moderna" como a de Debussy no Brasil. Além de provar que era capaz de compor como os músicos brasileiros já consagrados no ambiente musical, Villa-Lobos queria demonstrar estar além de todos os seus pares.

Esse exame de várias das composições produzidas por Villa-Lobos ao longo da década de 10 mostra que ele se preocupava em posicionarse em relação aos músicos eruditos da cidade do Rio de J aneiro. Para ser aceito por seus pares, ele devia seguir as regras estéticas do cenário musical erudito carioca. Isto incluía um afastamento em relação à música popular: chama a atenção o fato de que, na obra composta por Villa-Lobos ao longo da década de 10, é quase completa a ausência de elementos estéticos ligados à música popular, apesar do contato do compositor com os chorões. A música erudita feita por ele não tinha nenhum elemento declarada ou intencional mente nacional. Uma pesquisa atenta em seus arquivos revela que essa retórica e esse projeto praticamente não fizeram parte dos planos do compositor até sua ida a Paris, em $1923^{6}$.

A partir de 1915, Villa-Lobos começou a apresentar suas composições para o público carioca em recitais de música de câmara. A penas a quinta audição de suas obras, em 1918, constou de obras sinfônicas, o que se explica pela dificuldade do compositor em viabilizar um concerto com tantos integrantes. A pesar do fracasso financeiro e do pouco público presente a essa apresentação, as obras de Villa-Lobos foram muito elogiadas, e ajudaram a torná-lo mais conhecido. Seus esforços para estabelecer-se 
como grande nome da música erudita no Rio de J aneiro mostravam seus primeiros resultados.

Assim, em 1919, ele foi lembrado para compor uma das obras que seriam apresentadas no concerto em homenagem a Epitácio Pessoa, que retornava da Europa após ter participado da Conferência de Paris como representante do governo brasileiro. Das três obras executadas nesse dia, tematizando o fim da Primeira Guerra M undial, "A Guerra" foi deixada a encargo de Villa-Lobos, "A Vitória" foi composta por J . Otaviano Gonçalves, um laureado do Instituto Nacional de Música, e "A Paz" pelo já conhecido compositor Francisco Braga. Os jornais da época relatam como a obra de Villa-Lobos foi a mais aplaudida das três; a partir de então, ele começou a se afirmar como um dos grandes nomes do cenário musical brasileiro. Villa-Lobos passou também a ser prestigiado por artistas europeus de passagem pelo Rio de J aneiro, tendo suas obras executadas pelo pianista Arthur Rubinstein e pelo maestro alemão Felix Weingartner; duas sinfonias suas foram também executadas na ocasião da visita do rei da Bélgica à cidade, em setembro de 1920. De compositor marginal e desconhecido, Villa-Lobos tornava-se um nome comentado entre a alta sociedade carioca.

Foi então que Laurinda Santos Lobo, uma rica herdeira que promovia os salões artísticos mais célebres da cidade, resolveu apoiar a realização de concertos das obras do compositor. Em abril de 1921, em um concerto promovido por ela, no qual foi executado o quarto ato de Izaht, ele apresentou pela primeira vez algumas peças de temática "nacional": A Lenda do Caboclo, Viola e Sertão no Estio, obras que incluíam uma elaboração dos ritmos da música popular. Seu objetivo ao compor músicas "nacionais" foi por ele claramente explicitado em entrevistas aos jornais. Tratava-se de "iniciar a sua festa de arte por um concerto de peças musicaes de carater bem brasileiro, esperando, tambem, d'este modo chammar a atenção geral para esse lado das producções caracteristicamente nacionaes e artisticas, que devem figurar nos festejos do centenario" 7 . Villa-Lobos visava ao aproveitamento de suas obras nas festas do centenário da independência do Brasil, a ser comemorado no ano seguinte.

Logo, contudo, seus planos seriam alterados. Um segundo concerto promovido por dona Laurinda atraiu a atenção dos artistas modernistas paulistas; nele, Villa-Lobos apresentou suas obras mais "ousadas" esteticamente, como o Quartetto Simbolico e a peça A Fiandeira para piano solo, claramente inspirada na música de Debussy. A "modernidade" de Villa-Lobos - uma "modernidade" debussysta - fez com que ele fosse $o$ 
único compositor convidado para apresentar suas obras na Semana de Arte Moderna de São Paulo8.

A pós a Semana, os amigos e admiradores de Villa-Lobos começaram a articular sua ida a Paris - um passo tido como esperado para um músico que se tornava célebre no Brasil, caminho já tomado por tantos outros artistas. Ainda em 1922, um decreto federal liberou 40 contos de réis para que ele apresentasse obras suas e de outros compositores brasileiros na Europa. A penas metade desse dinheiro foi efetivamente liberada a tempo, antes do fim do ano fiscal de 1922; amigos e conhecidos de Villa-Lobos completariam de seus próprios bolsos o necessário para sua viagem (Guimarães 1972:231). Em junho de 1923, ele embarcou em direção a Paris.

Villa-Lobos chegou a Paris convicto de que faria sucesso. Ele deixou o Rio de J aneiro como um compositor de vanguarda no cenário musical da cidade. Em um ambiente musical dividido entre defensores da estética do bel-canto italiano, por um lado, e da estética al emã de Wagner ou da estética francesa de Saint-Saëns, por outro, ele via a si próprio como aquele que, superando seus pares, ousava compor de acordo com as revolucionárias idéias de Debussy. A certeza que ele tinha de seu sucesso está estampada na célebre afirmação que ele fez em uma entrevista dada logo que chegou à capital francesa: "Eu não vim aqui para aprender; vim mostrar o que fiz". Contudo, seu encontro com Cocteau foi o primeiro de uma série de acontecimentos que Ihe revelariam quanto ele estava enganado.

\section{Tornando-se brasileiro em Paris}

A exposição acima mostra-nos quais eram as ambições de Villa-Lobos e sua posição no meio artístico quando ele chegou a Paris, em junho de 1923. Em sua primeira reunião com artistas franceses, no studio de Tarsila, ele entrou em conflito com um artista que ocupava uma posição diametralmente oposta à sua. Se Villa-Lobos era um estrangeiro desconhecido recém-chegado à cidade, J ean Cocteau estava, então, completamente integrado nos meios artísticos parisienses, tendo mesmo conseguido impor-se como o grande artista de vanguarda da capital francesa. Vamos agora explorar a figura de Cocteau: entender quem ele era, por que não gostou da música que Villa-Lobos Ihe mostrou e por que sua opinião a respeito dela foi importante para o compositor brasileiro9.

Clément Eugène J ean $M$ aurice Cocteau nasceu dois anos depois de Villa-Lobos, em 5 de julho de 1889, na casa de seu avô materno, o agente de câmbio Louis-Eugène Lecomte, em cuja mansão repleta de quadros e 
objetos de arte, localizada na rica região de Maisons Laffite, a $20 \mathrm{~km}$ de Paris, ele passou sua infância.

Lecomte era um violinista amador, e fora amigo de Rossini - foi no piano do grande compositor italiano, que viveu boa parte de sua vida em Paris, que a mãe de J ean aprendeu a tocar o instrumento.

Durante sua adolescência, Cocteau começou a freqüentar os bastidores da Comédie Française. Ele teve acesso ao ambiente teatral graças a um amigo que participara de um curso de arte dramática e convivia diretamente com os atores. Esse contato foi fundamental para que o jovem J ean rapidamente se tornasse o grande nome jovem da arte francesa. Em 1908, Edouard de M ax, célebre ator da Comédie e parceiro nos palcos de Sarah Bernhardt, um dandy que vivia cercado de jovens rapazes, passaria a circular constantemente em companhia de Cocteau. Em abril do mesmo ano, as poesias do jovem artista foram recitadas por artistas conhecidos do público em uma matinê no Théâtre Fémina patrocinada por De M ax, e o principal crítico literário da época, Laurent Tailhade, fez uma conferência a seu respeito. $O$ grande número de convidados do grand monde da arte parisiense presente ao evento, as referências elogiosas do crítico e o empréstimo da celebridade dos atores às obras de Cocteau garantiram sua glória mundana imediata.

Ainda em 1908, De Max conseguiu inscrever o jovem poeta em uma sessão oficial do Salon des Poètes, presidido pelo ministro de Instrução Pública. Cocteau começou então a se relacionar com os grandes nomes da literatura francesa, como Catulle M endès e Marcel Proust, que em 1913 o escolheu para escrever uma crítica de seu Du Côté de chez Swann. Dessa forma, antes dos 20 anos de idade, ele estava presente nas casas e salões de arte mais inacessíveis. Mais que isso: sua presença de espírito, sua graça, seu charme e sua juventude fizeram dele uma das grandes atrações desses salões. Um dos participantes desses círculos diria dele: “Impossível ter mais espírito, mais graça poética na conversação [...]. Ele tinha ainda uma rara distinção e as mais belas maneiras do mundo. Em uma palavra, ele era irresistível" (apud Steegmuller 1973:56).

Sua convivência nesse meio iria torná-lo um dos mais conhecidos dandies da cidade. Por intermédio da esposa do editor de uma revista literária, ele teria acesso ao círculo que lideraria a vanguarda artística de Paris nos anos seguintes: a companhia de balés russos do empresário Serge Diaghilev. Assim, desde o início, J ean Cocteau esteve ligado ao verdadeiro epicentro vanguardista que era essa companhia. As apresentações dos balés de Diaghilev mobilizavam toda a alta sociedade e os meios artísticos da cidade, em um ambiente de intrigas e privilégios ao qual poucos ti- 
nham acesso livre. A partir do segundo concerto, Cocteau estaria sempre nos bastidores como um participante ativo, cuja simples presença já tinha significativo apelo publicitário. Em 1912, ele seria o autor do argumento de um dos espetáculos de Diaghilev, chamado Le Dieu Bleu.

A Primeira Guerra Mundial desordenou o ambiente artístico parisiense ao afastar críticos e artistas da cidade. Cocteau, no entanto, um rapaz franzino que fora declarado inapto ao serviço militar em 1910, serviu apenas por dois períodos (entremeados por longas licenças) como auxiliar de um serviço de ambulâncias próximo ao front, para tanto, provavelmente, também se beneficiando da influência de um tio diplomata. No final de julho de 1916, já estava definitivamente de volta a Paris. Ele ocuparia a partir de então uma posição privilegiada, como afirmaria alguns anos depois sobre esse período: “Em Paris o espaço estava livre. N ós o ocupamos" (apud Hurard-Viltard 1987:22).

Seu novo círculo de convivência durante a guerra incluía o pintor Pablo Picasso e o compositor Erik Satie. No final de agosto de 1916, os três artistas reuniram-se para organizar um novo espetáculo, que se chamou Parade. A presentado pela companhia de Diaghilev, esse bailado combinou ao texto de Cocteau os cenários e figurinos de Picasso e a música de Satie. O programa de Parade glorificava a música de rua, de circo ou de feira. J unto à música de Satie, era possível ouvir sons da rua, de máquinas de escrever, de uma sirene de navio, uma incorporação direta e não mediatizada do "popular" em uma produção "artística" revolucionária para a época.

Parade marcou época entre os artistas. Ao ser reapresentado em 1919 e 1920, conheceu também um grande sucesso de público, permitindo a Cocteau reivindicar para o espetáculo a origem de diversos movimentos de revolução estética nascentes na década de 20 . Parade marcou, sobretudo, o papel de destaque de Cocteau como definidor de tendências nas dinâmicas artísticas de Paris, grande pólo de atração cultural da época.

Em conseqüência desses acontecimentos, mesmo sem ser músico, Cocteau estava em posição de lançar um novo movimento musical em torno da figura de Erik Satie e seus discípulos. Satie, um compositor ativo desde antes do surgimento de Claude Debussy mas relegado a segundo plano, pôde ser apresentado pelo poeta como aquele que teria resguardado o verdadeiro "espírito francês" em suas composições musicais. As obras de Satie, diametralmente opostas às de Debussy, eram claras, simples e precisas; despojadas e sem rebuscamentos estéticos, não eram músicas que precisavam ser pensadas para ser entendidas. Estariam assim, segundo Cocteau, mais próximas das "músicas francesas da França" 
(apud Steegmuller 1973:155). Em 1918, o poeta publicou uma brochura intitulada Le Coq et l'A rlequin, cuja primeira edição se esgotou em pou$\cos$ dias $^{10}$. Composta em grande parte de aforismos espirituosos, essa pequena obra buscava definir o novo rumo a ser seguido pela "jovem arte" francesa após a guerra, e afirmava que o caminho da música era aquele definido por Satie e seus jovens seguidores ${ }^{11}$.

Temos agora os elementos necessários para entender o que ocorreu no encontro de J ean Cocteau com H eitor Villa-Lobos. Villa-Lobos chegou a Paris e foi conduzido diretamente ao centro da vanguarda artística, o ambiente em que se movimentava Cocteau. Todavia, o brasileiro chegou com uma obra inspirada pelas regras estéticas de Claude Debussy, justamente aquele compositor que Cocteau conseguira relegar à posição de uma geração anterior quando escreveu e publicou com sucesso Le Coq et I'A rlequin ${ }^{12}$. N essa situação, Villa-Lobos sofria o resultado da defasagem de sua cena artística de origem, que estava uma geração atrasada. Cabe lembrar que, em 1895, quando N epomuceno levou as partituras das obras de Debussy para o Rio de J aneiro, eram elas que constituíam a vanguarda na Europa. O próprio Nepomuceno, até sua morte, iria considerar Wagner como seu grande mestre, tendo que lutar contra a estética do bel-canto dos defensores do Império, mas ao mesmo tempo dando seu apoio para o surgimento de uma vanguarda debussysta na capital brasileira. No entanto, aquilo que era considerado moderno nos círculos musicais de vanguarda brasileiros não acompanharia o ritmo das mudanças na França, e assim Villa-Lobos já chegaria em Paris defasado.

Pode-se imaginar a decepção de Villa-Lobos quando, ao invés de ser aclamado ao mostrar suas obras "modernas" para artistas de vanguarda franceses, foi duramente criticado. $\mathrm{Na}$ verdade, o desentendimento entre Cocteau e Villa-Lobos pode ser visto como um curto-circuito entre as concepções que ambos portavam enquanto personagens de universos sociais muito distintos, apesar de tratarem da mesma manifestação cultural - a produção de música erudita ocidental moderna e anti-romântica. No Rio de J aneiro, Villa-Lobos era considerado ousado e vanguardista por utilizar elementos da estética de Debussy; em Paris, esse mesmo uso faria com que ele fosse criticado pelo principal representante da vanguarda.

Esse encontro foi apenas o primeiro momento de todo um processo de mudanças que sofreriam a partir de então as preocupações estéticas de Villa-Lobos. Ao longo do ano em que ele ficou em Paris, sua obra sofreu uma transformação significativa. Podemos entendê-la se seguirmos algumas pistas deixadas por Villa-Lobos e por pessoas próximas a ele na Paris de 1923. 
Na década de 20, Paris vivia o que seriam chamados os années folles - anos em que movimentos estéticos como o cubismo de Picasso, o dadaísmo de Tzara e o surrealismo de Breton competiram e se sucederam em grande velocidade. N esse ambiente, os artistas valorizavam o emprego de elementos considerados exóticos em Paris - a pintora Tarsila do A maral registra, por exemplo, em suas lembranças de Paris, a figura do "príncipe negro Tovalu", que era "um fetiche disputado em todos os meios artísticos de vanguarda" (Amaral 1975:104). As atitudes impulsivas de Villa-Lobos nos círculos artísticos que freqüentava e até mesmo seu porte físico agiriam no sentido de construir um lugar para ele enquanto compositor brasileiro - Villa-Lobos era certamente exótico para os refinados artistas parisienses. Basta citar aqui o depoimento do violonista Andrés Segovia ao recordar-se do dia em que conheceu o compositor:

“Dentre todos os convidados daquela noite, o que me causou maior impressão ao entrar na sala foi Heitor Villa-Lobos. A despeito de sua baixa estatura, era bem proporcionado e tinha um porte viril. Sua cabeça vigorosa, coroada com uma floresta selvagem de cabelos rebeldes era altiva [...]. Seu ol har briIhava com uma centel ha tropical que logo se transformou em uma chama, quando ele aderiu à conversação entretida ao redor. [...]

Quando terminei minha apresentação, Villa-Lobos aproximou-se e disse-me em tom confidencial: 'Também toco violão' - 'M aravilhoso!' respondi. 'Você é, então, capaz de compor diretamente para o instrumento'. Estendendo as mãos, ele pediu-me o violão. [...] E quando menos se esperava, desferiu um acorde com tal força, que deixei escapar um grito, pensando que o violão tinha se despedaçado. Ele deu uma gargalhada e com uma risada infantil disse-me: 'Espere, espere...' Esperei, refreando com dificuldade o meu primeiro impulso, que era o de salvar meu pobre instrumento de tão veemente e ameaçador entusiasmo" (apud Santos 1975:12).

Essa valorização do exótico, tão pregnante para um artista estrangeiro vindo da remota América13, encontrava eco em todos os círculos artísticos da capital francesa. Curiosamente, foi uma música brasileira que acabaria por batizar um dos maiores pólos de concentração da vanguarda artística parisiense nos années folles: o café Le Boeuf sur le toit.

O Boi no telhado foi uma canção composta pelo sambista Donga nos anos 10. Este samba, assim como muitas outras músicas populares brasileiras, foi ouvido pelo compositor Darius Milhaud quando ele morou no Brasil junto à missão diplomática francesa, entre 1917 e 1919. M ilhaud tornou-se um dos componentes do Grupo dos Seis, os jovens seguidores 
de Satie que seriam entronizados na vanguarda da música parisiense por J ean Cocteau. Quando voltou a Paris vindo do Rio de J aneiro, M ilhaud reuniu várias das composições que ouvira, transcreveu-as e colocou-as sob uma roupagem erudita "moderna", ligando-as por um tema musical recorrente; estava composta Le Boeuf sur le toit, uma "fantasia em forma de rondó sobre temas brasileiros". O Boeuf foi transformado em um balé com texto de Cocteau. M ilhaud, consistente com a proposta estética de Cocteau, afirmou que o que Ihe interessava nessas canções não era seu exotismo, mas "sua clareza de contornos, sua espontaneidade luminosa, seu humor imediato, sua intensidade interior": era a apropriação que um compositor francês de vanguarda dessa época poderia fazer de canções brasileiras ${ }^{14}$.

Foi outro, contudo, o projeto que Milhaud traçou para o uso da música popular brasileira por um compositor erudito brasileiro. Em "Brésil", um artigo publicado na Revue Musicale logo após seu retorno do Rio de $J$ aneiro, em 1920, ele afirmou que os músicos eruditos cariocas que conhecera não valorizavam a música popular de seu país. Perspicaz, M iIhaud percebeu o prestígio dos compositores franceses no Rio de J aneiro, e a distribuição de sua influência de acordo com a idade dos brasileiros:

“É lamentável que todas as composições de compositores brasileiros, desde as obras sinfônicas ou de música de câmara dos srs. [Alberto] Nepomuceno e [Henrique] Oswald até as sonatas impressionistas do sr. [Oswaldo] Guerra ou as obras orquestrais do sr. Villa-Lobos (um jovem de temperamento robusto, cheio de ousadias), sejam um reflexo das diferentes fases que se sucederam na Europa de Brahms a Debussy e que o elemento nacional não seja expresso de uma maneira mais viva e mais original. A influência do folclore brasileiro, tão rico em ritmos e de uma linha melódica tão particular, se faz sentir raramente nas obras dos compositores cariocas. Quando um tema popular ou o ritmo de uma dança é utilizado em uma obra musical, esse elemento indígena é deformado porque o autor o vê através das lentes de Wagner ou de Saint-Saëns, se ele tem sessenta anos, ou através das de Debussy, se ele tem apenas trinta" (Milhaud 1920:61).

Por outro lado, M ilhaud elogiou no mesmo artigo os músicos populares cariocas. Segundo ele,

“[...] seria desejável que os músicos brasileiros compreendessem a importância de compositores de tangos, de maxixes, de sambas e de cateretês como Tupynamba ou o genial [Ernesto] Nazareth. A riqueza rítmica, a fantasia 
indefinidamente renovada, a verve, o ânimo, a invenção melódica de uma imaginação prodigiosa, que se encontram em cada obra desses dois mestres, fazem deles a glória e a alegria da Arte brasileira" (M ilhaud 1920:61).

Ao lermos os escritos dos brasileiros que formavam o círculo inicial de relações de Villa-Lobos em Paris, percebemos o quanto uma atitude positiva em relação à produção de arte "nacional" passou a ser valorizada por todos eles na capital francesa. Em uma carta enviada de Paris à revista A riel, por exemplo, o poeta Sérgio M illiet afirmou:

“É um grande erro considerar-se o maxixe música sem importância. Ele representa parte da nossa alma, e a alma de uma raça é coisa serí́ssima. J ustamente, o que devemos cultivar são os elementos espontâneos brotados em nosso povo. Devemos partir dos seus característicos, a ingenuidade, a sensualidade, a melancolia e o chiste da modinha para, com estes dados, chegarmos a uma música nossa, e portanto, universal" (Milliet 1924:215).

Tarsila do A maral iria mais além. Em uma carta escrita para seus pais em abril de 1923, poucos meses antes da chegada de Villa-Lobos a Paris, ela disse:

\begin{abstract}
"Sinto-me cada vez mais brasileira: quero ser a pintora da minha terra. Como agradeço por ter passado na fazenda a minha infância toda. As reminiscências desse tempo vão se tornando preciosas para mim. Quero, na arte, ser a caipirinha de São Bernardo, brincando com bonecas de mato, como no último quadro que estou pintando [Tarsila desenha um esboço do quadro que chamou de A Caipirinha]. Não pensem que essa tendência brasileira na arte é mal vista aqui. Pelo contrário. $\mathrm{O}$ que se quer aqui é que cada um traga contribuição do seu próprio país. Assim se explicam o sucesso dos bailados russos, das gravuras japonesas e da música negra. Paris está farta de arte parisiense (apud Amaral 1986:76).
\end{abstract}

Tarsila afirma claramente como a valorização da arte "nacional" brasileira não era, em sua opinião, restrita aos brasileiros. Segundo ela, eram os próprios parisienses que queriam conhecer as produções culturais de outras nações - o que explicaria essa súbita ênfase no elemento nacional por artistas anteriormente tão convertidos à estética francesa. De fato, se atentarmos às críticas publicadas a respeito dos poucos concertos das obras de Villa-Lobos dirigidos por ele nessa primeira viagem à Europa, perceberemos que apenas as obras que continham algum elemento assi- 
milável à sua nacionalidade eram elogiadas. Um crítico português escreveu sobre um desses concertos:

“[...] desprezando a imitação dos moldes europeus wagnerianos ou debussystas e aparecendo muito oportunamente com uma feição exótica, no momento em que os artistas do Velho Mundo, cansados de impressionismo e de cerebralismo, se voltam para uma arte forte e rude de ossatura rítmica, embora selvagem e extravagante [o crítico refere-se à obra de Stravinski], o moço compositor brasileiro entendeu bem que deveria seguir o seu próprio caminho e dele em nossa opinião nunca deverá se desviar, antes nos parecendo que deve cada vez mais aperfeiçoar a técnica especial requerida pelo seu modo de sentir individual e rácico" (Branco apud O Rio Musical 1920:10).

Assim, quando Villa-Lobos chegou a Paris em 1923, toda uma série de pequenos contatos e interações, cujas pistas estivemos aqui perseguindo, agiu no sentido de convencê-lo aos poucos da imperiosa necessidade de sua conversão, de sua transformação em um compositor de músicas de caráter nacional. Como conseqüência, ele deixaria de tentar compor de acordo com as regras estéticas de compositores franceses, tão valorizadas no Brasil, para tentar retratar sua nação musicalmente, um projeto especialmente valorizado na França.

Um primeiro reflexo da viagem de Villa-Lobos a Paris pode ser encontrado nas entrevistas que ele deu. Vejamos o que ele afirmou ao jornal A Noite, em 9 de janeiro de 1922, antes da viagem, preocupado em defender suas composições diante dos que o acusavam de ter formação erudita precária:

“As eras assírias, as relíquias esculturais da Coréia, o misticismo da Índia, o amor abnegado do culto de beleza entre os Visigodos, a melopéia romana, a Epopéia grega, as excursões gregorianas, que legaram à humanidade essa beleza eterna do canto-chão, influíram fortemente sobre certos aspectos da minha estética" (A N oite, 9/1/1922).

Vejamos agora sua opinião em uma entrevista dada ao mesmo jornal logo antes de sua segunda viagem à Europa, em 9 de janeiro de 1926:

“É na formação das artes de um país, que existe a cega necessidade imprescindível de colher os principais motivos na sua própria natureza, como fizeram todas as grandes nações que mais se distinguiram pela sua maneira própria de ser, algumas delas chegando mesmo a dominar o espírito artístico 
universal, implantando sugestivamente um Belo que nada tem de comum com o Belo de outros povos de temperamentos completamente opostos. É verdade que nestes casos resulta sempre num curioso fenômeno de condições e paradoxos. Por exemplo, (sem ironia) no Brasil [...] veneram com eloqüência todos os feitos da Grécia/Roma antiga e ridicularizam as façanhas dos nossos primitivos selvagens. [...] É isso que se chama talvez, modernamente, esnobismo" (A N oite, 9/1/1926).

É fácil também perceber as mudanças que se deram em suas composições. Villa-Lobos começou enfim a utilizar amplamente em suas composições os ritmos da música popular, com os quais convivia fora dos teatros no Brasil, mas que não tinha incorporado em suas criações devido ao valor negativo atribuído à estética popular pelos músicos eruditos brasileiros - uma das características mais marcantes de suas obras seria a partir de então a riqueza rítmica, pouco utilizada anteriormente. Logo após voltar de Paris, em 1924, ele pesquisou também cantos indígenas, ouvindo no M useu Nacional os fonogramas gravados por Roquette Pinto durante a expedição Rondon, em 1908 - várias de suas composições utilizaram a partir de então trechos desses cantos. A estética de Debussy foi abandonada, e o uso da orquestra passou a inspirar-se no Stravinski "primitivo" da Sagração da Primavera.

Assim, Villa-Lobos começou a retratar em suas composições toda uma série de representações a respeito de sua nação. Com o tempo, desenvolveu uma linguagem própria e inconfundível, criando uma síntese musical original entre o panorama musical erudito europeu contemporâneo e as músicas folclóricas e populares brasileiras. Estudiosos como Gilberto Freyre viriam a considerar que Villa-Lobos teria concentrado em si a essência da música nacional.

“Direi que, no caso de Villa-Lobos, ele parece ter sido influenciado, como carioca, em grande parte, por impactos sociais, e direi que esses impactos sociais se tornaram nele sócio-musicais. É um assunto para um estudo detaIhado do que se pode chamar, ao lado de uma sócio-lingüística, uma sóciomusicalidade. [...] Vamos imaginar que, como sócio-músico, ele começou a absorver em si influências sócio-musicais vindas para um morador, como ele, quando plasticamente jovem, de um Rio de J aneiro, capital na época do Brasil, como sons não abstratamente sons porém sons sociais confluentes, que viessem a confluir nele, carioca, dando-Ihe uma perspectiva trans-carioca, ultra-carioca, pan-brasileira. Villa-Lobos foi, decerto, assim, sócio-músico, um dos maiores compositores que o mundo tem visto, um pan-brasileiro supre- 
mo, não só carioca, não só do sul do Brasil, mas um pan-brasileiro que chegou a compreender os Brasis mais remotos, os mais remotamente gaúchos, os mais remotamente amazônicos." (Freyre 1982:10)

Percebemos pela leitura feita por Gilberto Freyre como todo o processo que levou Villa-Lobos a tornar-se um compositor "nacional" foi esquecido por estudiosos de sua obra, que preferiram idealizar sua "essência" brasileira. Suas composições anteriores à sua ida a Paris seriam mesmo vistas por historiadores de viés nacionalista como obras "imaturas", de um artista que não tinha ainda achado sua linguagem e sua "essência nacional" (ver, p. ex., Mariz 1989:111; Kiefer 1981:47). No entanto, se a originalidade das obras posteriores do compositor é indiscutível, também é inegável que na raiz de seu projeto se encontram claramente as concepções francesas a respeito do Brasil e de como deveria ser uma música brasileira. Afinal, a representação de Brasil que esse "sociomúsico" foi capaz de sintetizar em suas composições não é qualquer representação, mas aquela do Brasil selvagem, exótico, virgem, o Brasil da natureza, dos índios e dos ritmos primitivos. Em suma, o Brasil imaginário dos parisienses.

\section{Definindo-se a partir do olhar estrangeiro}

A pós 1923, J ean Cocteau prosseguiria sua acidentada carreira artística, chegando a ser eleito membro da Académie Française em 1955; sua trajetória não sofreria nenhuma inflexão perceptível em função do encontro com o compositor brasileiro. Para Villa-Lobos, ao contrário, o encontro com Cocteau pode ser tomado como momento exemplar do início de um processo conversivo ao final do qual ele se tornaria um artista brasileiro, compondo apenas músicas de caráter nacional e dando depoimentos emocionados sobre seu pertencimento à nação.

Contudo, essa não era uma conseqüência necessária, não era uma característica intrínseca à possibilidade de criação do compositor. Como vimos, o francês Darius M ilhaud pôde apropriar-se de músicas brasileiras para compor obras "francesas", afirmando ser atraído por sua "clareza". Já Villa-Lobos, um brasileiro, apenas poderia utilizar as mesmas obras para exprimir um suposto exotismo de seu país natal.

O fato de Villa-Lobos ter começado a compor músicas brasileiras a partir de 1923 deveu-se não à descoberta de que ele teria uma essência brasileira, mas sim a um processo de transformação que foi colocado em marcha por uma série de mecanismos sociais de atribuição de valor. 0 
papel da Semana de 22 em sua trajetória foi exagerado por seus biógrafos e estudiosos, que atribuíram a esse evento papel decisivo na transformação de Villa-Lobos em um compositor preocupado com a música brasileira.

Ao longo deste artigo, ao contrário, tento demonstrar que o projeto de Villa-Lobos para fazer uma música "brasileira" de acordo com a concepção francesa de "Brasil" foi a resultante de uma série de práticas articuladas de diversos atores sociais, por exemplo: as opiniões dos brasileiros que viviam em Paris com Villa-Lobos, os comentários da crítica, as reações dos artistas que o cercavam às suas atitudes, o imaginário que Ihe transmitiam a respeito de seu país.

A grande questão, portanto, é por que Villa-Lobos acatou a definição de Brasil e o papel de compositor brasileiro que Ihe foi atribuído na Europa. Devemos, então, nos perguntar: por que os objetivos artísticos que Villa-Lobos passou a perseguir foram aqueles formulados por artistas europeus - ou por artistas brasileiros após terem contato com europeus? Por que o projeto dos franceses para uma arte "brasileira" se impôs com tanta naturalidade, se opções estéticas são escolhas arbitrárias e não naturais? Enfim, como explicar a maior legitimidade da visão dos franceses a respeito de como deveria ser uma arte "brasileira"?

Para responder a estas perguntas, devemos considerar que Villa-Lobos tinha o projeto de ser aceito e aclamado pelo establishment musical parisiense. Ou seja: antes de tudo, ele reconhecia o julgamento dos parisienses como válido e legítimo. A ssim como uma série de artistas e intelectuais brasileiros anteriores e contemporâneos a ele, Villa-Lobos reconhecia e admirava a civilização francesa. $\mathrm{O}$ arquiteto Pereira Passos, por exemplo, construiu um Rio de J aneiro baseado nas reformas que viu em Paris; os literatos brasileiros do final do século XIX reencenavam nas ruas do Rio de J aneiro a existência boêmia descrita pelo francês Henri Murger em Scènes de la vie de Bohème ${ }^{15}$; Alberto N epomuceno reconstituía $a$ admiração francesa por Wagner no Instituto Nacional de M úsica ao mesmo tempo que criava condições propícias para o surgimento de uma vanguarda debussysta; o compositor Leopoldo Miguéz escrevia a um amigo que estava em Paris afirmando que

“[...] se não fora umas tantas dificuldades que não pude vencer, achar-me-ia neste momento, com minha mulher, em Paris, gozando os encantos desse paraíso terrestre; ouvindo, e vendo tudo que por aí é digno de ouvir-se e verse. Quanto é belo tudo isso! E quanto é nulo o que por aqui se faz! Muita razão têm os patrícios, como o amigo [o escritor e folclorista] Sant'Anna Nery 
e outros, em preferirem viver na pátria das belas-artes e do progresso, a vegetar neste degredo, neste país de botocudos!" (apud Pereira 1995:75).

Villa-Lobos era, enfim, mais um dos participantes desse regime de relações entre França e Brasil. Inúmeras práticas como essas criaram, legitimaram e naturalizaram a atribuição de um valor superior a estéticas e definições da civilização francesa. M ediante o acompanhamento da trajetória de Villa-Lobos, podemos perceber como ele e uma série de produtores de uma "cultura brasileira" acataram as definições, opiniões e estéticas de artistas europeus, constituindo-se como brasileiros no espelho por eles fornecido.

Recebido em 25 de outubro de 2001

A provado em 10 de dezembro de 2002

Paulo Renato Guérios é mestre em antropologia social pelo PPGAS/M useu Nacional/UFRJ e doutorando na mesma instituição. Estudou a trajetória de vida de Heitor Villa-Lobos em sua dissertação de mestrado, Lutando por sua Predestinação. Um Estudo Antropológico da Trajetória de Heitor Villa-Lobos, a ser publicada pela Fundação Getulio V argas Editora em 2003. Está atualmente realizando um estudo sobre trajetórias de vida e memória entre descendentes de imigrantes ucranianos no Estado do Paraná. 


\section{Notas}

* Agradeço as sugestões da profa. Lygia Sigaud e dos dois pareceristas anônimos que avaliaram este artigo. Seu conteúdo, no entanto, é de minha inteira responsabilidade.

1 A história dessa reunião foi relatada pela própria Tarsila e por Souza Lima, respectivamente, em Amaral (1975:104) e Lima (1969:153).

2 A "modernidade" da proposta de Miguéz e Nepomuceno refletia-se também no esforço pela construção de um lugar para o músico erudito no Brasil. Um campo começava a ser criado com um mínimo de consistência, em contraposição à absoluta precariedade da vida dos músicos brasileiros durante o Império. Havia uma instituição de ensino bem estabelecida, funcionando adequadamente e ocasionando um forte e apaixonado debate estético. M úsicos de sólida formação traziam da Europa as mais fortes tendências estéticas, e lutavam por implementálas. A idéia de se chegar à "civilização" por via da música ressurgia, agora como um projeto imiscuído à "modernidade" das idéias republicanas.

3 As informações sobre os pais de Villa-Lobos e sua relação com eles foram obtidas a partir de uma pesquisa de fontes primárias nos arquivos do M useu VillaLobos, no Rio de J aneiro, e do livro de L. Guimarães (1972), cunhado do compositor. Essa pesquisa sobre Villa-Lobos resultou em minha dissertação de mestrado (Guérios 2001), onde a trajetória do compositor é tratada em maiores detalhes.

4 Há uma gravação completa do N aufrágio de Kleonicos, regida pelo próprio compositor, no arquivo do M useu Villa-Lobos. O clímax dessa obra é um excerto bastante conhecido do repertório do compositor, O Canto do Cisne Negro, claramente inspirado na canção O Cisne, de Camille Saint-Saëns - não apenas o nome, mas a estética romântica, um acompanhamento de arpejos e o instrumento solo, o violoncelo, são os mesmos da canção de Saint-Saëns.

5 Entrevista concedida à crítica musical Suzanne Demarquez, publicada na Revue Musicale de novembro de 1929 e reproduzida em Guimarães (1972:149).

6 Alguns autores, como Kiefer (1981:103), lembram de obras como as Canções Típicas Brasileiras, que teriam sido compostas em 1919, para tentar refutar essa tese. Contudo, muitas obras foram redatadas pelo compositor a posteriori, como essas canções. Isto é facilmente comprovado por vários indícios espalhados pelos arquivos a respeito de Villa-Lobos: por exemplo, Viola Quebrada, uma das Canções, era baseada em um tema criado por M ário de Andrade e dedicado a Tarsila e Oswald de Andrade, que não estavam ainda juntos em 1919. Além disso, o programa de um concerto de Villa-Lobos em 1923 contém uma lista de todas as suas composições até então, e as ausências de inúmeras obras nessa lista são reveladoras de sua redatação (cf. Guérios 2001:160). 
7 Recorte de jornal não identificado, datado de 13/6/1921, pertencente ao acervo do M useu da Imagem e do Som/RJ .

8 A relevância da Semana de Arte M oderna na trajetória de Villa-Lobos tem sido exagerada pelos estudiosos (ver, entre outros, M ariz 1989:111 e Andrade 1991 [1939]:25). Isso talvez se deva ao fato de que ela foi um marco no cenário artístico nacional, visto que os artistas que ocuparam o establishment da arte no país a partir de então foram os envolvidos na Semana. Assim, projeta-se a relevância do evento sobre a trajetória do compositor. No entanto, a Semana apenas teve importância posterior para Villa-Lobos por torná-lo mais conhecido fora do Rio de Janeiro e por marcá-lo como "modernista" diante de um importante crítico musical carioca, Oscar Guanabarino (cf. Guérios 2001:122-125). A Semana não teve, ao contrário do que se afirma, influência na conversão de Villa-Lobos a uma música nacional ou em sua projeção no panorama artístico nacional.

O meu argumento difere significativamente daquele defendido por uma das obras mais célebres a respeito de Villa-Lobos e da Semana de Arte M oderna: a dissertação de mestrado O Coro dos Contrários: A Música em torno da Semana de 22 (1983), de J osé M iguel Wisnik. Wisnik faz uma leitura muito sofisticada a respeito do assunto. Em razão da falta de espaço, posso traçar apenas algumas linhas gerais da análise proposta pelo autor, já que seria impossível fazer aqui uma crítica minuciosa de uma obra tão densa e tão rica em idéias (para um exame um pouco mais detalhado, cf. Guérios 2001:181-184, n. 72). Wisnik desenvolveu seu trabalho no início da década de 70, quando leituras marxistas e pós-marxistas estavam muito em voga nas universidades do país. O instrumental analítico que ele utiliza (com extrema consistência) advém da Sociol ogie de la M usique, de Adorno. Wisnik procura, mediante uma análise da substância musical das obras apresentadas por Villa-Lobos na Semana, detectar a significação social que estaria organicamente presente em seu interior, com o "social" entendido como uma totalidade que engloba os indivíduos. Em suas palavras: "procuro fazer um levantamento geral dos procedimentos técnicos que essas obras põem em circulação, para procurar definir, em última análise, que tipo de orgânica as preside e a que sentido ideológico (ou sentidos) podem corresponder" (Wisnik 1983:141). Segue-se uma cuidadosa leitura estética de algumas obras, durante a qual o autor encontra elementos de uma "selvageria" característica de Villa-Lobos misturados ao "refinamento" de Debussy - isto é identificado exemplarmente em um trecho das Danças Características Africanas que é “baseado modalmente nas escalas de Debussy [no caso, a escala de tons inteiros] e ritmicamente no gingado da síncopa" (Wisnik 1983:151).

A mudança ocorrida na produção musical de Villa-Lobos nos anos que se seguiram à Semana até 1930, quando o compositor passou a enfatizar especialmente o ruído e abandonou as técnicas modais de Debussy para adotar idéias ligadas à quebra tonal criadas por Stravinski, aparece para Wisnik como "a eclosão [nas obras de Villa-Lobos] de um mundo selvagem, natural" que seria, em uma primeira instância, a "projeção de seus impulsos pessoais, ou 'íntimos'” (Wisnik 1983:166), conforme Mário de Andrade afirmara em trecho citado pelo autor. Não se tratava, no entanto, para Wisnik, de uma pura confluência de expectativas. As obras apresentariam tanto um significado estético (percebido pelos promotores da Semana) quanto um sentido social englobante: "as forças desencadeadas nas pe- 
ças de Villa-Lobos tocam nesse campo de possibilidades, onde o requinte da evolução das forças produtivas de uma sociedade tendente ao refinamento da tecnificação se junta [...] à emergência de um denso e diversificado mundo de possibilidades da natureza". Assim, a produção de Villa-Lobos pós-1922, segundo Wisnik, além de ocorrer

“[...] como resultante [...] de sua complexa personalidade [ou seja, do indivíduo Villa-Lobos], resulta também de uma coordenada coletiva, que é a necessidade de representar a imagem de uma natureza pujante de recursos, a evidenciar as enormes potencialidades da nação, a projetar uma visão positiva das suas possibilidades. O problema é complexo, mas pode ser tratado a partir de uma idéia de Adorno, segundo a qual o talento se forma no encontro de certas linhas tendenciais de necessidades presentes num meio social, que o plasma conforme suas expectativas" (Wisnik 1983:167).

Desse modo, a música de Villa-Lobos antes de 1922 teria agenciado técnicas de Debussy como uma maneira de libertar um nacionalismo que já estava presente. Já a música posterior a 1922 seria o resultado da combinação do indivíduo Villa-Lobos com um ambiente social englobante que o teria "plasmado" de acordo com a necessidade de representar um país voltado para o futuro, com energia para realizar-se, com potencial para explodir. N ote-se, contudo, que o "social" que teria "plasmado" a música de Villa-Lobos é decodificado pelo autor como sendo as próprias idéias modernistas! Wisnik toma uma das posições presentes em um campo de lutas estéticas como a totalidade da "arte brasileira" naquele momento histórico.

Os trechos citados a seguir por Wisnik justificam a si mesmos: citações de quatro autores (M ário de Andrade, Ronald de Carvalho, Coelho N etto e um fragmento de Andrade M uricy escrito 35 anos depois) que vêem na música de VillaLobos o “jorrar de água” e o “libertar de energias” demonstrariam que o compositor encarnaria uma expectativa, representando em sua música o "país imaginado como potencial" (Wisnik 1983:170); Villa-Lobos, enfim, moldado por esse "social" que englobaria a todos, acaba por ser o próprio país em forma de música. A análise de Wisnik exime-se, assim, de ver as pequenas interações que influíram nas decisões de Villa-Lobos, englobando seu caminho sob as idéias modernistas; e apaga, enfim, o próprio Villa-Lobos enquanto ator social, ao não ver o tanto que ele próprio trabalhou para conseguir influir nos rumos de sua trajetória.

9 As informações a respeito da trajetória de J ean Cocteau foram extraídas de duas biografias a seu respeito: os livros de Kihm et alii (1968) e Steegmuller (1973), além de Hurard-Viltard (1987).

${ }^{10}$ Cocteau publicou Le Coq et l'A rlequin em sua própria editora, mais uma demonstração de sua posição central e de seu acesso direto a recursos importantes na definição do cenário artístico parisiense.

11 Estes últimos iriam tornar-se célebres: dois anos mais tarde, um artigo de um crítico musical chamado "Les Cinq Russes et les Six Français" emprestaria no- 
va legitimidade à liderança desse grupo de seguidores, que seriam a partir de então conhecidos como “o grupo dos Seis". Eram eles: Louis Durey, Germaine Tailleferre, Darius Milhaud, Arthur Honneger, Francis Poulenc e Georges Auric.

12 Bourdieu (1977:39) enfoca a questão da “inovação” artística, mostrando que os círculos de vanguarda que conseguem impor suas visões estéticas têm necessariamente que remeter as visões dominantes no seu campo artístico a um " passado" estético. Ou seja, um novo artista apenas pode vir a ocupar uma posição de prestígio se impuser uma visão estética discordante em relação àquela de um artista consagrado, relegando-o ao passado e construindo para si próprio uma imagem de novidade e ousadia.

${ }^{13}$ Artistas latino-americanos de outros países passaram em Paris pelo mesmo processo sofrido por artistas brasileiros como Tarsila e Villa-Lobos. O escritor e musicólogo cubano Alejo Carpentier, por exemplo, elogiava a expressão do exótico em Villa-Lobos, demonstrando o quanto a representação francesa a respeito de uma "A mérica Latina" era pregnante para os artistas "nativos" que iam à Europa e se viam assim reunidos sob uma mesma representação. Em artigo publicado na Gaceta M usical, de julho/agosto de 1928, ele escreveu: “Domingo à tarde. No studio de Villa-Lobos [...] o admirável pianista Tomás Terán se senta ao piano. Executa prestigiosamente uma suite de Cirandas de Villa-Lobos... E a voz formidável da América, com seus ritmos de selva, suas melodias primitivas, seus contrastes e choques que evocam a infância da humanidade, soa no calor da tarde de verão, através de uma música refinadíssima e muito atual. A encantação surte efeito. Os martelos do piano - baquetas de tambor? - gol peiam mil lianas sonoras, que transmitem ecos do continente virgem. $E$, ante o discurso da palmeira que pensa como palmeira, cala-se por um instante, como avergonhada, a fonte da praça Saint Michel".

${ }^{14} \mathrm{M}$ ilhaud iria se apropriar mais vezes das obras que ouvira no Brasil: em 1920, comporia Saudades do Brasil; o movimento final de sua Scaramouche (1937) se chamaria Brazileira, consistindo de uma série de variações sobre o tango brasileiro Brejeiro, de Ernesto N azareth; em 1945, comporia ainda as três Danses de J acaremirim: Chorinho, Tanguinho e Sambinha.

${ }^{15} \mathrm{~A}$ respeito da importância cultural da França no Rio de J aneiro da época em que Villa-Lobos cresceu, ver Needell (1987). 


\section{Referências bibliográficas}

AMARAL, A. 1975. Tarsila. Sua Obra e seu Tempo. São Paulo: Edusp. . 1986. Tarsila. São Paulo: Patrocínio Tenenge.

ANDRADE, M. 1991 [1939]. Aspectos da Música Brasileira. Belo Horizonte: Vila Rica.

AZEVEdo, L. H. C. 1936. “As Primeiras Óperas". Revista Brasileira de Música, III.

. 1938. “A Imperial Academia de Música e Ópera Nacional e o Canto Vernáculo (1857-1963)". In: Anais do I Congresso da Língua N acional Cantada. São Paulo: Departamento de Cultura.

BENSA, A. 1998. “Da Micro-História a uma Antropologia Crítica". In: J . Revel (org.), J ogos de Escalas. A Experiência da Micro-Análise. Rio de J aneiro: Fundação Getulio Vargas Editora. pp. 43-66.

BOURDIEU, P. 1977. “La Production de la Croyance. Contribution a une Économie des Biens Symboliques". Actes de la Recherche en Sciences Sociales, 13:4-43.

FREYRE, G. 1982. Villa-Lobos Revisitado. Transcrição de palestra proferida no Festival Villa-Lobos. Manuscrito.

GUÉRIOS, P. R. 2001. Lutando por sua Predestinação. Um Estudo Antropológico da Trajetória de Heitor Villa-Lobos. Dissertação de Mestrado, PPGAS/Museu Nacional/UFRJ .

GUIMARÃES, L. 1972. Villa-Lobos Visto da Platéia e na Intimidade. Rio de Janeiro: $s / e$.

HURARD-VILTARD, E. 1987. Le Groupe des Six ou Le Matin d'un J our de Fête. Paris: Meridiens Klincksieck.

KIEFER, B. 1981. Villa-Lobos e o Modernismo na M úsica Brasileira. Porto Ale- gre: Movimento.

KIHM, J., SPRIGGE, E. e BEHAR, H. C. 1968. J ean Cocteau. L'Homme et ses Miroirs. Paris: Ed. de la Table Ronde.

LIMA, J . deS. 1969. “O Villa-Lobos que Eu

Conheci". Presença de Villa-Lobos, 1:151-169.

LINO, J . s/d. O Gênio da Música Popular Brasileira em Paranaguá. M anuscrito.

MARIZ, V. 1949. Heitor Villa-Lobos, Compositor Brasileiro. Rio de J aneiro: Divisão Cultural do Ministério das Relações Exteriores.

. 1989. Heitor Villa-Lobos, Compositor Brasileiro (11a ed.). Belo Horizonte: Itatiaia.

MELLO, G. T. D. 1947 [1908]. A Música no Brasil. Desde os Tempos Coloniais até o Primeiro Decênio da República (2a ed.). Rio de J aneiro: Imprensa Nação.

MILHAUD, D. 1920. “Brésil”. La Revue Musicale, 1:60-61.

MILLIET, S. 1924. “Carta de Paris por Sérgio Milliet". A riel, I(6):214-216.

NEEDELL, J . 1987. A Tropical Belle Époque: Elite, Culture and Society in Turnof-the-Century Rio de J aneiro. Cambridge: Cambridge University Press.

O RIO MUSICAL. 1920. Rio de J aneiro, II(40). "Villa-Lobos".

PEREIRA, A. 1995. Música, Sociedade e Política: Alberto Nepomuceno e a República Musical do Rio de J aneiro (1864-1920). Dissertação de M estrado, Departamento de História/ UFRJ .

SANTOS, T. 1975. Heitor Villa-Lobos e o Violão. Rio de J aneiro: MEC/M useu Villa-Lobos.

STEEgm ULLER, F. 1973. Cocteau. Paris: Buchet Khastel.

WISNIK, J . M . 1983. O Coro dos Contrários. A M úsica em torno da Semana de 22. São Paulo: Duas Cidades. 


\section{Resumo}

Este artigo pretende discutir o regime de funcionamento dos fluxos culturais entre um grande centro e um sistema periférico, tomando como exemplo os ambientes musicais da França e do Brasil na década de 20. As trajetórias de vida de dois personagens, o poeta e pintor francês J ean Cocteau e o compositor brasileiro Heitor Villa-Lobos, são tomadas como pontos de referência para atingir tal objetivo. A análise do material estudado permite demonstrar como os próprios atores sociais pertencentes à periferia acabam por subordinar-se ao julgamento dos atores sociais do centro, acatando suas definições a respeito dos critérios que definem a validade interna de suas produções.

Palavras-chave Heitor Villa-Lobos, Cultura Nacional, M úsica Brasileira, Fluxos Culturais
This article discusses how the flux of cultural productions between center and periphery works, taking as an example the field of music production in France and Brazil in the 1920s. The life trajectories of $\mathrm{J}$ ean Cocteau, french poet and painter, and Heitor Villa-Lobos, a brazilian composer, are taken as reference for the discussion. It is concluded that the social actors in the periphery tend themselves to accept the opinions and judgements of the social actors in the center, taking for granted their definitions on the criteria that validate their productions.

Key words Heitor Villa-Lobos, Brazilian Music, National Culture, Cultural Flows 